\title{
Undergoing Re-negotiations between Pakistan and China for Free Trade Agreement
}

\author{
Hamid Mukhtar* \\ Lahore High Court Bar Association
}

\section{Background}

Pakistan and China have a long history of friendly diplomatic as well as economic relations. Both countries are bounded in a number of bilateral treaties including China-Pakistan Bilateral Investment Treaty ("CPBIT") ${ }^{1}$ and China-Pakistan Free Trade Agreement ("CPFTA"). Recently, both countries are undertaking a joint project namely China Pakistan Economic Corridor ("CPEC"), which is an important part of the Belt and Road Initiative ("BRI"). CPFTA was signed in November 2006 and entered into force in July 2007. ${ }^{3}$ Moreover, the two countries signed the Agreement on Trade in Service of the CPFTA in 2009 which came into effect in the same year. ${ }^{4}$ Trade and investment volume between Pakistan and China has been increasing as the result of mentioned agreements. Presently, Pakistan has become the second largest trading partner of China in South Asian region. ${ }^{5}$ However, CPFTA has been more favorable for China. Chinese exports to Pakistan have increased to an alarming situation, while Pakistani exports to China have not been increased significantly. Therefore, Pakistan's trade deficit with China has gained the shocking situation. ${ }^{6}$ Pakistani producers complain that the CPFTA 2006 was only favoring China. ${ }^{7}$ Currently, both countries are re-negotiating the CPFTA in order to create a balanced situation of bilateral trade and investment. ${ }^{8}$ The renegotiations are aimed at overcoming the imbalance of trade that exists between

* Advocate High Court, Lahore, Punjab, Pakistan. LL.B. (Punjab Univ.), LL.M. (Wuhan), S.J.D. (ZJU). ORCID: https://orcid.org/0000-0002-1803-4490. The author may be contacted at: hamid_ mukhtar41@yahoo.com/Address: Room No 206, Building No 10, XiXi Campus, Zhejiang University, Wensan Road, West Lake District, Hangzhou, 310007 P.R. China. 
the two countries. ${ }^{9}$ This essay encompasses the latest developments made under the re-negotiations of CPFTA.

\section{Re-negotiations for CPFTA, Why?}

CPFTA was scheduled to be implemented in two phases. It was agreed that two parties would liberalize 90 percent tariff lines by the end of second phase. ${ }^{10}$ Phase I of the CPFTA implementation was completed in December 2012, while negotiations for the phase II were initiated in July 2013. ${ }^{11}$ Nine rounds of meetings for negotiations under CPFTA phase II have already been conducted, but until now parties have not been reached to a conclusion due to Pakistan's demand for the re-negotiation of FTA considering the afresh terms and conditions. Pakistan has been requesting for the unilateral market access to Chinese market. However, China has been refusing it on the ground that there was no such provision available in the original CPFTA. ${ }^{12}$ Finally, China has agreed to accommodate the demands made by Pakistan to revise the CPFTA. The following are reasons why Pakistan has been demanding for the re-negotiation of CPFTA.

\section{Pakistan's Domestic Market}

Pakistani government has been facing a huge pressure from the local Pakistani producers and businessmen who rightly claim that excess of Chinese products in Pakistani market has destroyed the local industry. ${ }^{13}$ Pakistani industry is in developmental phase now and the local producers of Pakistan are not in a position to provide products as cheap as Chinese ones. Also, local Industries of Pakistan are at risk due to huge dumping of Chinese goods into the Pakistani market. ${ }^{14}$

\section{Trade Deficits}

The Chinese goods have become instantly popular in Pakistan due to their low price. When Pakistani products are sent to China, however, those are not sold being expensive. Pakistan is not in a position to avail the offers made by China under CPFTA due to high manufacturing cost of its products. Excessive imports of Chinese products into Pakistan continuously raised the Pak-China trade deficit from USD 2859 million (2008) to USD 12,090 million (2016), which is the largest deficit of Pakistan with any trading partner. ${ }^{15}$ Trade deficit between Pakistan and 
China has been growing in favor of China and against Pakistan due to the one sided trade dimension under CPFTA.

Pakistan has only utilized less than 5 percent of the concessions available under CPFTA, while, on the other hand, China has utilized more than 55 percent of the concessions available under CPFTA. ${ }^{16}$ Although 7,550 products (at EightDigit HS Code) were covered under CPFTA 2006 in China's offer list to Pakistan, but Pakistani exports were recorded in 350 product lines only which constitute 4.64 percent of the total concessional products. ${ }^{17}$ On the other hand, Chinese exports to Pakistan were recorded in 3800 products out of 6803 products that were placed in Pakistan's offer list to China. Hence, China has been successful in utilizing 55.87 percent out of the total products. ${ }^{18}$

\section{Tariff Concessions}

The tariff concessions which have been provided to Pakistan under CPFTA by China appear to be generous in the first instance. However, for those products in which Pakistan has a comparative advantage, China has offered equal or even higher concessions to the ASEAN countries. ${ }^{19}$ For instance, tariff reductions under the category of 100 percent concession were reduced to 10 percent by China for Pakistan in 2011. These products account for 35 percent of the total products on which concessions have been provided by China under CPFTA. ${ }^{20}$ Conversely, tariff rates for the ASEAN were reduced to zero (0) percent by China on the similar products. ${ }^{21}$ Therefore, Pakistani side claims that Pakistan's margin of preference has been eroded due to China's FTAs with other countries including the ASEAN member countries. ${ }^{22}$ Previously, Minister for Commerce of Pakistan Khurram Dastgir Khan in an interview stated: "Our margin of preference has been eroded by the subsequent accords China has done, first address this imbalance, and then of course we can begin to negotiate further expansion and liberalization. ${ }^{, 23}$

\section{Non-concession Products}

Importantly, rise in Pakistani exports has also been recorded in exports of those products which have not been provided concessions under CPFTA. Although demand for those products in China is huge, Pakistan is contributing less than 1 percent in the supply of those products to China. It shows that the products in which Pakistan has the expertise with the comparative advantage have not been 
covered under CPFTA. On the other hand, concessions offered by Pakistan to China under CPFTA appear to be more favorable for China in terms of variety of Products (Types of Products). ${ }^{24}$

\section{Current Status of CPFTA Re-negotiations}

Negations for CPFTA phase II were started in 2013, but again dragged due to Pakistan's reservations on the agreement. China agreed to accommodate Pakistan's concerns on CPFTA during the ninth round of negotiations held in Beijing. ${ }^{25}$ During two days' negotiations China agreed on making amendments to CPFTA by providing Pakistan with tariff concessions equal to those of the ASEAN. ${ }^{26}$ Moreover, during the latest round, China agreed further with Pakistan to discontinue tariff concessions on some of the Chinese imports to Pakistan for the protection of Pakistan's domestic industry. ${ }^{27}$ Since the latest round of negotiations, Chinese side has been evidently willing to leverage the Pakistani concerns for the balance of trade between two countries. The revised version of CPFTA is expected to be signed later in 2018.

\section{Conclusion}

China-Pak trade has been increasing as a result of landmark FTA concluded between them. The condition of trade between the two countries suggests that China has been benefiting more from CPFTA due to its stable economic situation and favorable concessions provided by Pakistan under CPFTA. On the other hand, Pakistan has not as benefited from CPFTA as was being expected before the lunch of free trade with China. Today, trade deficit of Pakistan with China has reached to an alarming situation. Therefore, in order to create a balanced position of trade between the two countries, it is necessary that revised CPFTA should provide equal benefits to both parties so that the two countries may draw benefit from mutual trade under the new agreement. 


\section{REFERENCES}

1. China and Pakistan signed bilateral investment treaty (CPBIT) in 1989. See CPBIT, available at http://tfs.mofcom.gov.cn/aarticle/h/at/201002/20100206778604.html (last visited on Aug. 3, 2018).

2. See CPEC, available at http://cpec.gov.pk (last visited on Aug. 3, 2018).

3. See CPFTA, available at http://fta.mofcom.gov.cn/topic/enpakistan.shtml (last visited on Aug. 3, 2018).

4. Id.

5. H. Mukhtar, China's Free Trade Agreements under Negotiations, China \& WTO Rev. 167-73 (2018).

6. Pak-China FTA, available at https://www.dawn.com/news/1388405 (last visited on Aug. 3, 2018).

7. See FTA with China: Pakistan offers to scrap duties on $50 \%$ of products, available at https://tribune.com.pk/story/821418/fta-with-china-pakistan-offers-to-scrap-duties-on-50of-products (last visited on Aug. 3, 2018).

8. H. Mukhtar \& Q. Hongdao, A Critical Analysis of China-Pakistan Free Trade Agreement: Learning Experiences for Pakistan with respect to its Future FTAs, 5(6) Global J. Politics \& L. REs. 63-74 (2017)

9. Mubarak Zeb Khan, Pakistan seeks changes in free trade agreement with China, DAwn, Sept. 9, 2017, available at https://www.dawn.com/news/1356432 (last visited on Aug. 3, 2018).

10. See Pakistan, China agrees on terms of FTA Phase II, available at https://nation.com. pk/26-May-2018/pakistan-china-agree-on-terms-of-fta-phase-ii (last visited on Aug. 3, 2018).

11. CPFTA, supra note 2 .

12. Id.

13. Id.

14. Supra note 7.

15. Mukhtar \& Hongdao, supra note 8.

16. Id

17. See Preliminary study on Pakistan and China trade partnership post FTA, available at https:// www.pbc.org.pk/wp-content/uploads/21-Oct_Pakistan_China_Trade_Study_2013.pdf (last visited on Aug. 3, 2018).

18. Id.

19. Mukhtar \& Hongdao, supra note 8.

20. Id.

21. For details, see Pak-China FTA: China's Offer list, available at https://www.tdap. gov.pk/pdf/CN-offer(Cat- 2).pdf; ASEAN-China Free Trade Agreement (ACFTA), 
China's Offer list, available at http://www.mtib.gov.my/repository/woodspot/website acfta_23july09.pdf (all last visited on Aug. 3, 2018).

22. China has provided Pakistan with zero duty only on 35 percent of the total tariff lines, compared with over 90 percent to Malaysia, Indonesia, Philippines and Thailand, provided under ACFTA.

23. K. Haider \& I. Dilawar, Growing Trade Imbalance Leads Pakistan to Seek China Concessions, BLoOmBerg, June 27, 2017, available at https:/www.bloomberg.com/news/ articles/2017-06-27/growing-trade-imbalance-leads-pakistan-to-seek-china-concessions (last visited on Aug. 3, 2018).

24. Mukhtar \& Hongdao, supra note 8.

25. Staff reporter, China agrees to accommodate Pakistan's concerns on FTA, DAwn, Feb. 9, 2018, available at https://www.dawn.com/news/1388207 (last visited on Aug. 3, 2018).

26. See China agrees to accommodate Pakistan's concerns on trade agreement, available at https://www.geo.tv/latest/181138-china-agrees-to-accommodate-pakistans-concerns-ontrade-agreement (last visited on Aug. 3, 2018).

27. Id. 